\title{
Reminiscences of Childhood for Confessional
}

\section{Poets}

\author{
Dr. Tasneem Anjum
}

Associate Professor \& Head, Department of English, Pratibha Niketan College, Nanded. Maharashtra, India. tasneemanjum1961@yahoo.com

\begin{abstract}
Childhood is a fascinating experience for one and all, more so for a poet, as his/her experience as a child, is responsible for the later development in life. Experiences at this stage are raw, emotional, inarticulateoften expressed though gestures and sounds. But the same experience takes on larger meaning after a few years, when they are viewed objectively. Ruminating over the past events, putting the clock back, imagining with intensity and expressing them through a language which is provocative and beautiful; suggestive and intriguing, this nostalgia for childhood is one of the distinctive aspects of confessional poetry. The profile of the baby as 'pure', happy and carefree child without tensions or problems, is pervasively found in their poems. This strain of nostalgia, critics feel, is inevitable as they look at the future as uncertain which does not augur much hope; the present is full of tensions and contradictions, which seem unresolved; as such the poets are tempted. Sometimes forced to look back on their past for recapturing happier moments.
\end{abstract}

Keywords-Childhood, Nostalgia, Father, Grandmother, Sea, Treasure, Landscape.

Really what keeps us apart

At the end of years is unshared childhood. You cannot, for instance

(Love Poem for a wife) Ramanujan

As confessional poets, both Sylvia Plath and Kamala Das have drawn concrete images of their childhood in their poems. There is however a striking difference in their response to events in childhood. Kamala Das seems to be much more emotional in her responses than Sylvia Plath. Plath seems to filter or refract her experiences more through the people she knew. As such in Kamala Das, even the landscape acquires meaning and significance as an extension of her memories, so that it externalises her interior sensibility. Kamala Das, thus, used the landscape more effectively in the background, to add a further dimension to her poems.

But, lying beside my grandmother,

Quite often I thought

That I could hear at night

The surf breaking on the shore

('Composition')

The sea imagery is powerful and meaningful because of its association with her grandmother. "Grandmother's House" at Nalapat makes the title and also the central theme of her poetry. As a child when she could not adjust herself to the boarding school, she was sent to her grandmother's house at Nalapat which becomes her 'paradise,' she says:

It had been clear to me that my home was broken up for incomprehensible reasons. My mother was living in Malabar while my father stayed at Culcutta. It was not a complete family like everybody elses ... ${ }^{1}$

She could not help falling in love with her grandmother who

...was really simple.

Fed on God for years

All her feasts were monotonous

For the only dish was always God

('Blood')

She was the woman who kindled the royal ego of Kamala Das. She always imagined herself to be a born aristocrat and played a 'queen' in her dreams and also the plays in which she took part. In later years, after marriage, when she became aware of her middle class life, the nostalgia becomes stronger. The frustration is reflected in the poem:

There was a house now far away where once I received love.... That women .... You cannot believe, died darling 
Can you, that I lived in such a house and was proud and loved. . . I who have lost My way and beg now at stranger's door receive love, at least in small change.

('My Grandmother')

The vital role played by the grandmother was also taken up by 'Grumpy' of Plath. When Sylvia Plath was a child, her parents were young and busy in pursuing their academic career or struggling to establish a marital rapport. During these stuffy unloved years, the grandparents made an entry into the childhood world of Sylvia and added "their humour, love and laughter to that too academic atmosphere." 2 She was taught to read and write when she barely two and a half years old. Artistic by temperament, the child grew up and was ready to welcome her brother warren when he was born. Plath's attachment to her grandmother is evident in the poem'Point Shirley'

A labour of love and that labour lost

Steadily the Sea

Eats at point Shirley. She died blessed and I come by.

Bares bones only pawed and tossed

A dog faced sea.

This poem, 'point Shirley' evokes the tragic theme of impermanence of human experience. Plath moves from the general to the particular in the reflection of her own grandmother, prompted, presumably by her visit to their old house which had withstood the hurricane, gallantly. ${ }^{3}$

The house still stands on the steadily encroaching sea. This brings out her intense sense of desolation and hostility of the natural world against which only her grandmother might have offered protection. This sense of security she found in her grandmother was reinforced by her father's death. She clings to her more desperately along with grandmother too. There is a fusion of her father and grandmother says Plath's mother in her preface to Letters Home. ${ }^{4}$ Essentially, Plath was her father's girl. Ottoplath wanted his first child to be a girl. He doted on her and "his love for the child took the form of enthusiastic, scientific, pedantry, so that, a four, she was a female imitation of him naming number of insects in Latin."

Plath adored her father. This gave way to that love/hate relationship and felt strongly that he was solely responsible for her unhappiness later in life. His untimely death, when she was just eight and a half years old made her feel desolate. She curses him for that
Daddy, I have had to kill you

You died before I had time-

Marble-heavy, bag full of God

('Daddy')

Kamala Das and Plath, both the poets, can be termed as child prodigies. They started writing poetry at a very young age. They inherited their literary taste from their mother. Plath remembers her mother reading aloud Mathew Arnold's "Forsaken Herman"; she responded immediately and intensely. Her first publication appeared in "Boaston News Papers" when she was just eight years old. ${ }^{6}$
Hero the cricket chirping
In the dewy grass.
Bright little fireflies
Twinkle as they pass.

\section{('Poem')}

This is a poem from a child, who is aware of and responsive to her natural surroundings and she later described the subject of this and other early childhood poems as

Nature, I think: birds, bees, springs, fall all those subjects which are absolute gifts to the person who does not have any interior experience to write about. I think, the coming of spring, the stars over head, the first snow fall and so on are gifts for a child, a young poet. $^{7}$

Kamala Das too was barely "Six and very sentimental" when she started writing poetry. She wrote tragic poems about her dolls which lost their heads and limbs and confesses that "each poem of mine made me cry." It was no surprise that she had such intense feelings as she was left to herself. She could not fit into the 'English' boarding school or get used to the idea about her mother being lonely and detached and her father so deeply involved in politics. Thus as a first and last resort, she turned to writing. Kamala Das had a fine library at Nalapat and her grand uncle Narayan Menon was a famous poet of his time. The whole atmosphere of the Nalapat house was influenced by Gandhiji. Gandhiji was not considered as a person who fought for our independence alone, but "was considered one among the family members." 10 In such an atmosphere, the child, Kamala Das, left alone by her, fed herself on poetry. 
There is a vivid description of her childhood days in her autobiographical novel My Story and a few chapters are devoted to her growing up stages, whereas, Plath's life story starts when she was a teenager.

In Bell Jar, she counts upon her experience from that stage, when she won the Mademoiselle prize for her story, which got her a paid-trip to New York and a guest editorship as well. This does not mean that she didn't have any strong feelings about her childhood. Her mother quotes her poems in her collection Letters Home ${ }^{11}$

My world was warm with April Sun

My thoughts were spangled green and

My soul filled up with Joy, yet gold felt

the shap, sweet pain that only Joy can hold

('I thought that I could not be hunt')

This was the world of Sylvia Plath which had occasional disturbance. This poem was written when one of her favourite paintings got smudged, accidentally, by her grandmother. Her restraint, not to be very sensitive about simple things, took the form of poems which won the admiration of her teachers as well. "Incredible that one so young could have experienced anything so devastating" 12 says her English teacher Mr. Cockett.

Plath grew up with the same restraint which made her a good academician and a creative artist in her later life. For, poetry is a genre where the intense feelings are expressed with maximum restraint. She grew up too hastily. The sea-side childhood was over, although it was recalled later, as a time of remote, perfect happiness:

And this is how it stiffens, my vision of that sea-side childhood. My father died, we moved inland. Where on those nine first years of my life sealed them-selves off like a ship in a bottle-beautiful, inaccessible, obsolete, a fine white, flying myth. ${ }^{13}$

The tragic experience of losing her father was tried to be compensated by her loving and understanding mother; her grandparents who showered all their affection on her, was no compensation at all. The suffering of her beloved father, which she had witnessed in her early stages as a child, had left an indelible mark on her poetry. She wrote a series of poems referred to as "Bee poems" by critics. The heavy Bee Box was like a "coffin" and it was "dark." The noise of the bees which appealed to her was like "Roman mob" with "unintelligible syllables." She felt she was "no source of honey" and realized the "bitter position" of hers without her father. All these phrases from her various poems suggest the inheritance of interest of father's Beekeeping.
But, for Kamala Das, childhood was not a disjointed process but a continuous experience. She was scared of growing old and could not accept it till was reminded about it.

My grandmother cried,

Darling, you must stop this bathing

You are much too big to play naked now in the pond.

('The Suicide')

Growing up was a tragedy for her.

The tragedy of life

Is not death but growth

The child growing into adult

And growing out of needs,

Discovering that the old have lack rimmed nails

('Composition')

Kamala Das never excused her father for putting an abrupt end to her childhood by pushing her into a hasty arranged marriage, when she was just content with tenderness. It shattered all her dreams of childhood.

The excess nostalgia for childhood forms the basis of many poems of both Kamala Das and Sylvia Plath. The sea appears as imagery in most of their poems which they adored and treasured as childhood experiences.

\section{REFERENCES}

[1] Kamala Das, My story (New Delhi, 1977), p. 3

[2] Aurelia Schober Plath, ed., Letters Home (New York, 1975), p. 11.

[3] Eileen Arid, Sylvia Plath (Edinburgh, 1973), p. 25.

[4] Aurelia Schober Plath, ed., Letters Home, p. 22.

[5] Ibid., p. 87.

[6] Aurelia Schober Plath, ed., Letters Home, p. 75.

[7] Peter orr, The Poet Speaks (London, 1976), p. 167.

[8] Kamala Das, My Story, p. 8.

[9] Ibid.

[10] Ibid., p. 11.

[11] Aurelia Schober Plath, ed., Letters Home, p. 25.

[12] Ibid.

[13] Sylvia Plath, “Ocean 1212-W' In Newmary ed., The Art of Sylvia Plath (London, 1973), p. 272. 